\title{
Post-Caesarean section analgesia: a comparison of epidural butorphanol and morphine
}

Epidural butorphanol 1,2 and $4 \mathrm{mg}$ were compared with morphine, $5 \mathrm{mg}$, for postoperative analgesia in 92 consenting, healthy, term parturients who had undergone Caesarean section under epidural lidocaine anaesthesia in a randomized doubleblind study. Postoperative pain was assessed using a visual analogue scale and recorded with heart rate, blood pressure and respiratory rate. The demographic characteristics, and the incidences of primary and repeat Caesarean sections, were not different ainong the four trearment groups. At 15, 30, 45 and 60 min after treatment the median pain scores following butorphanol were similar and lower than those following morphine $(P<$ $0.05)$. Calculated median percentage pain relief values for butorphanol were higher than morphine at each of these times $(P$ $<0.05)$. At $90 \mathrm{~min}$ and $2 \mathrm{hr}$ the pain scores and pain relief values were similar. Beyond $45 \mathrm{~min}$ the number of patients requesting supplemental medication and dropping out of the study increased progressively in both the butorphanol and morphine treated patients. The attrition profiles for butorphanol were different from morphine $(P<0.01)$. The median time in the study was $>24 \mathrm{hr}$ for morphine, and 3, 2.5 and $4 \mathrm{hr}$ for butorphanol, 1, 2 or $4 \mathrm{mg}$, respectively. No patient developed a clinically important change in heart rate or blood pressure, and none experienced a decrease in respiratory rate below 12 breaths. min $^{-1}$. One of 69 patients ( 1.4 per cent) who received butorphanol developed pruritus compared with ten (43 per cent) of 23 patients who received morphine. The global assessments of

\section{Key words}

ANALGESIA: epidural, obstetrics, postoperative; ANALGESICS: butorphanol, morphine.

From the Departments of Anesthesiology and Surgery, Baylor College of Medicine, Houston, Texas 77030

Presented in part at the Socicty for Obstetric Anesthesia and Perinatology, Salt Lake City, Utah, May 15-18, 1986 and The 61st Congress of the International Anesthesia Research Society, Lake Buena Vista, Florida, March 14-18, 1987.

Address correspondence to: Dr. Q.T. Palacios, Department of Anesthesiology, 435D, Baylor College of Medicinc, One Baylor Plaza, Houston, Texas 77030.

Accepted for publication 29 th August 1990.
Quisqueya T. Palacios MD, Monica M. Jones MD, Joy L. Hawkins MD, Jayshree N. Adenwala MD, Stephen Longmire MD, Kenneth R. Hess ms, Barbara S. Skjonsby RN, Dean H. Morrow MD, Thomas H. Joyce III MD the adequacy of analgesia were indistinguishable berween morphine and butorphanol. Epidural butorphanol provides safe, effective postoperative analgesia, has a prompt onset, and a limited duration.

Dans une étude à double insu lors de césarienne chez 92 parturientes à terme, nous avons comparé l' efficacité de 1, 2 et 4 mg de butorphanol à celle de $5 \mathrm{mg}$ de morphine injectés dans le cathéter employé pour l'anesthésie épidurale à la lidocaïne. Nous jaugions la douleur postopératoire sur une échelle visuelle analogue et mesurions le pouls, la tension artérielle et la fréquence respiratoire. Les variables démographiques et la proportion de césariennes itératives étaient semblables dans les quatre groupes. Les valeurs médianes d'intensité douloureuse 15, 30, 45 et 60 min après l'injection de butorphanol étaient les mêmes pour les trois doses et étaient inférieures à celle de la morphine $(P<0,05)$; en même temps, les pourcentages médians de soulagement étaient plus grands avec le butorphanol $q u^{\prime}$ avec la morphine $(P<0,05)$. Toutefois, à 90 min et $2 \mathrm{~h}$ post injection, ces variables étaient les mêmes pour les deux morphiniques. A partir de la 45ième minute, de plus en plus de patientes traitées à la morphine ou au butorphanol nécessitaient d' autres analgésiques, mettant ainsi un terme à leur participa. tion à l'étude mais à une fréquence différente selon le morphinique $(P<0,01)$. La durée médiane de participation à l'étude était de plus de 24 h pour la morphine et de 3,2,5 et 4 h pour les doses de l, 2 et $4 \mathrm{mg}$ de butorphanol respectivement. /l n'y eut pas de modification clinique du pouls ou de la tension artérielle non plus que de bradypnée à moins de $12 \mathrm{~min}^{-1}$. Une seule des 69 patientes ( 1,4 pour cent) ayant reçu du butorphanol se plaint de prurit mais 10 des 23 patientes (43 pour cent) du groupe morphine firent de même. L'évaluation globale de l'efficacité analgésique était la même pour la morphine et le butorphanol. Le butorphanol épidural offre une analgésie postopératoire sûre et efficace; il agit rapidement et pendant une période limitée.

The use of epidural morphine for the relief of postoperative pain after Caesarean section is associated with prolonged analgesia, a decreased requirement for supplemental narcotics, early ambulation and improved 
maternal-infant bonding. ${ }^{1-8}$ Morphine, a pure opioid agonist, primarily activates mu receptors and may induce the undesirable side-effects of respiratory depression, pruritus, nausea, vomiting, and sedation..$^{9-12}$ In addition, the poor lipid solubility of morphine results in a slow onset of action, and is believed to be the cause of respiratory depression by cephalad spread of the drug to the respiratory centres by migration in the cerebrospinal fluid, ${ }^{13}$

Butorphanol, a synthetic opioid, is a strong kappa receptor agonist, a weak mu receptor agonist/antagonist, and is relatively lipid soluble. ${ }^{14-16}$ For these reasons, the use of epidural butorphanol for post-Caesarean section analgesia should produce less respiratory depression and a reduced incidence of pruritus, nausea, and vomiting. The present study, a triple-blind, randomized evaluation, was conducted to compare the responses to three doses of butorphanol with morphine for providing postoperative epidural analgesia, and to assess the side-effects of each drug following Caesarean section.

\section{Methods}

The study was approved by the Institutional Committees on Human Research and written informed consent was obtained from each patient. Ninety-two healthy parturients at term who had undergone a successful delivery by Caesarean section under epidural anaesthesia were enrolled. These were patients at a large urban county hospital affiliated with Baylor College of Medicine. Patients with evidence of major organ disease, a substance abuse history, or a major complication of pregnancy were excluded. The age, height, weight, ethnic background and Caesarean section history of each patient were recorded

Anaesthesia for the Caesarean section $\left(T_{4}\right.$ sensory level) was produced with lidocaine, two per cent with 1:200,000 epinephrine, injected through an epidural catheter inserted in the $\mathrm{L}_{2-3}$ or $\mathrm{L}_{3-4}$ interspace. The epidural catheter was left in place. During resolution of the epidural block, postoperative pain was evaluated at 15 min intervals using a $100 \mathrm{~mm}$ visual analogue scale where $0=$ "no pain" and $100=$ "worst pain ever." Each patient was instructed to mark the scale at the point which she felt was representative of her level of discomfort. When the patient indicated that her pain was "moderate" (5-6 scale units or more), a single dose of test drug was injected and the epidural catheter removed. Selection of the test drug was based on a computer-generated randomization schedule. Each dose of medication was prepared by the hospital pharmacy and supplied in identically appearing coded vials. The test medications were morphine, $5 \mathrm{mg}$, and butorphanol 1, 2, or $4 \mathrm{mg}$. Each was preservative-free, and diluted to a total volume of ten $\mathrm{ml}$ with sterile saline at the time of injection. The anaesthetist, the research nurse and the patient were blinded as to which drug/dose was administered.

Each patient was instructed that she could request supplemental medication at any time. Following the test drug, repeated measurements of pain were made using the same visual analogue scale for $24 \mathrm{hr}$ or until the patients requested supplemental analgesia. The measurement intervals were: $15,30,45,60$ and $90 \mathrm{~min}$, and $2,3,4,6,8$, 12,16 , and $24 \mathrm{hr}$. Measurements of respiratory rate, blood pressure and heart rate were recorded before the test drug was administered, and at intervals during the time the patient remained in the study. These measurement intervals were: 30,60 and $90 \mathrm{~min}$, and 2, 2.5, 3, 4, 6, 8, 12, 16 and $24 \mathrm{hr}$. The mean blood pressure ([systolic diastolic/3] + [diastolic]) was calculated. Each patient was observed for the incidence of adverse side effects, including nausea and/or vomiting, pruritus and a decrease in the respiratory rate to less than 12 breaths $\cdot \min ^{-1}$. Patients who developed clinically "mild" pruritus were given intravenous diphenhydramine $25 \mathrm{mg}$, while those developing clinically "moderate" pruritus were given intravenous naloxone in increments of $0.8 \mathrm{mg}$ titrated to effect. The choice of treatment was left to the discretion of the responsible anacsthetist. When a patient requested supplemental medication, data from the time interval immediately preceding the request were used as the end of her participation in the study. The drug(s), dose(s) and route(s) of administration for the supplemental medication(s) were not standardized. These decisions were, again, made by the responsible anaesthetist on the basis of his/her assessment of the clinical situation. Each patient who received supplemental medication was observed for a minimum of $24 \mathrm{hr}$ because of the late respiratory depression known to occur with one of the test medications, morphine. $9,11,12$ At the end of the period of observation, each patient was asked to provide a global evaluation of the adequacy of her epidural analgesia using the following scale:

$$
\begin{aligned}
& 0=\text { no relief } \\
& 1=\text { poor relief } \\
& 2=\text { fair relief } \\
& 3=\text { good relief } \\
& 4=\text { very good relief } \\
& 5=\text { excellent relief }
\end{aligned}
$$

After the study was completed, the code was broken and the patients sorted into four groups on the basis of the study drug/dose administered. The pain score measurements were rounded to the nearest $0.5 \mathrm{~cm}$ for analysis. The visual analogue scale (VAS) provided a continuousvalued numeric measure of pain with values from 0 to 10 . However, pain assessment was necessarily subjective 
such that two individuals with the same level of pain may mark the scale in different locations based on their discomfort tolerance and past experience with painful stimuli. We felt, therefore, that it was reasonable to treat VAS pain assessment data as ordinal rather than intervalscaled. In addition, the pain scores were markedly asymmetric in many subgroups. Thus, when possible, non-parametric, rank-based methods were used to the analyze the data. ${ }^{17}$ The data analyses were performed using the BMDP statistical software package (BMDP Statistical Software, Inc., Los Angeles). The percentages of pain relief, the relationship between pain intensity after epidural drug administration to the intensity prior to administration was calculated (per cent pain relief $=$ [baseline - treatment]/[baseline]). These values provided a standardized index of pain relief with each patient serving as her own control. ${ }^{18}$ Categorical data were compared using the Pearson chi-squared test. The continuous-valued variables, pain scores and percentage pain relief values, were compared statistically using the Kruskal-Wallis test. Since the data were asymmetric they are reported as median (first quartile, third quartile). The first quartile is equivalent to the 25 th percentile, the median to the 50th percentile and the third quartile to the 75th percentile. The asymmetry in the data can be judged by comparing the relative distances of each quartile from the median. The interquartile range $(I Q R=$ third minus first quartile), is a reasonable (i.e., resistant to outliers) index of dispersion for an asymmetric distribution. For normally (Gaussian) distributed data, the median $\pm 2 / 3$ IQR can be considered a reasonable estimate of the mean \pm one standard deviation. ${ }^{19}$ Significance was established by $P<0.05$

\section{Results}

Twenty-three patients received morphine. Twenty-two, 23 and 24, respectively received butorphanol, 1,2 or 4 $\mathrm{mg}$. The four treatment groups were not statistically significantly different with respect to age, height, weight or ethnicity (Table I). There were 13 primary and ten
TABLE II Suplemental medications by subject groups

\begin{tabular}{|c|c|c|c|c|c|c|c|}
\hline \multirow{3}{*}{\multicolumn{2}{|c|}{ Supplement, mg }} & \multirow{4}{*}{$\frac{\text { Rte }}{\mathrm{IM}}$} & \multicolumn{4}{|c|}{ Subject group } & \multirow{4}{*}{$\frac{T o t}{7}$} \\
\hline & & & \multirow{3}{*}{$\frac{\frac{M S}{5 m g}}{0}$} & \multicolumn{3}{|c|}{ Butorphanol } & \\
\hline & & & & \multirow{2}{*}{$\frac{1 \mathrm{mg}}{0}$} & \multirow{2}{*}{$\frac{2 \mathrm{mg}}{4}$} & \multirow{2}{*}{$\frac{4 \mathrm{mg}}{3}$} & \\
\hline Meper & 50 & & & & & & \\
\hline Meper & 50 & $\mathrm{IM}$ & 3 & 4 & 3 & 2 & 12 \\
\hline Prometh & 25 & & & & & & \\
\hline Meper & 75 & IM & 3 & 11 & 8 & 8 & 30 \\
\hline Prometh & 25 & & & & & & \\
\hline Meper & 75 & IM & 0 & 0 & 0 & 1 & I \\
\hline Hydrox & 25 & & & & & & \\
\hline Meper & 75 & IV & 1 & 1 & 2 & 1 & 5 \\
\hline MS & 8 & IM & 0 & 1 & 0 & 2 & 3 \\
\hline MS & 10 & IM & 0 & 1 & 1 & 1 & 3 \\
\hline MS & 6 & IM & 0 & 1 & 0 & 0 & 1 \\
\hline Prometh & 25 & & & & & & \\
\hline MS & 8 & IM & 1 & 0 & 2 & 1 & 4 \\
\hline Prometh & 25 & & & & & & \\
\hline MS & 10 & IM & 1 & 2 & 0 & 1 & 4 \\
\hline Prometh & 25 & & & & & & \\
\hline MS & 8 & IM & 0 & 0 & 1 & 0 & $\mathbf{I}$ \\
\hline Hydrox & 25 & & & & & & \\
\hline MS & 10 & IM & 0 & 0 & 1 & 1 & 2 \\
\hline Hydrox & 25 & & & & & & \\
\hline MS & 4 & IV & 0 & 0 & 1 & 0 & 1 \\
\hline Butorph & 2 & IM & 0 & 0 & 0 & 1 & 1 \\
\hline Butorph & 1 & IV & 0 & 0 & 0 & 1 & 1 \\
\hline Codeine & 60 & PO & 0 & 0 & 0 & 1 & 1 \\
\hline Meper $=$ & Mepe & & & Butorph & $=$ Butor & anol & \\
\hline Prometh $=$ & Prom & azine & & Ric & $=$ Roule & admini & ation \\
\hline Hydrox $=$ & Hydrc & & & Tot & $=$ Total & & \\
\hline MS $=$ & Morp & ie sulfate & & & & & \\
\hline
\end{tabular}

repeat Caesarean sections in the morphine-treated patients. The corresponding numbers for butorphanol, 1, 2 or $4 \mathrm{mg}$, were: 10 and 13,11 and 12 , and 15 and 8 respectively. The differences between primary and repeat sections were not significant. The drugs, doses and routes of administration of the supplemental medications are shown in Table II.

TABLE I Subject age, height, weight and ethnicity

\begin{tabular}{|c|c|c|c|c|}
\hline \multirow[b]{2}{*}{ Variable } & \multirow{2}{*}{$\begin{array}{l}\text { Morphine } \\
5 \mathrm{mg}\end{array}$} & \multicolumn{3}{|l|}{ Butorphanol } \\
\hline & & l mg & $2 \mathrm{mg}$ & $4 m g$ \\
\hline Age, yr & $23(21,28)$ & $24(21,23)$ & $23(20.26)$ & $23.5(21.5,27)$ \\
\hline $\mathrm{Ht}, \mathrm{cm}$ & $63(61.65)$ & $62.5(60.64)$ & $62(60,64)$ & $62(60.5 .65 .5)$ \\
\hline$W_{t}, \mathrm{~kg}$ & $165(147,178)$ & $156.5(144,194)$ & $150(144,182)$ & $155(143,173)$ \\
\hline \multicolumn{5}{|l|}{ Ethnicity } \\
\hline White & $3(13 \%)$ & $5(23 \%)$ & $4(17 \%)$ & $6(25 \%)$ \\
\hline Black & $11(48 \%)$ & $3(14 \%)$ & $6(26 \%)$ & $4(17 \%)$ \\
\hline Hispanic & $9(39 \%)$ & $14(64 \%)$ & $13(57 \%)$ & $14(58 \%)$ \\
\hline
\end{tabular}


TABLE III Subject pain score values, median (Ist, 3rd quartile)

\begin{tabular}{lllll}
\hline \multicolumn{5}{c}{ Subject group } \\
\cline { 2 - 5 } Time & Morphine & \multicolumn{3}{c}{ Butorphanol } \\
\cline { 2 - 5 } min/hr & $5 m g$ & Img & $2 m g$ & $4 m g$ \\
\hline Baseline & $6(5,9)$ & $5(4,7)$ & $6(5,7.5)$ & $7(5,9)$ \\
15 & $4(2,8)$ & $2(0,4)$ & $1(0.3)$ & $1(0,2)$ \\
30 & $2.5(1,6.5)$ & $0(0,2)$ & $0(0.1)$ & $0(0,1)$ \\
45 & $2(0,6)$ & $0(0,1)$ & $0(0,1.5)$ & $0(0,1)$ \\
60 & $3(0,5)$ & $0(0,0.5)$ & $0(0,1)$ & $0(0,1)$ \\
90 & $0(0,2)$ & $0(0,1.75)$ & $0(0,1)$ & $0(0,1)$ \\
2 & $0(0,2)$ & $1(0,5)$ & $0(0,5)$ & $1(0,4)$ \\
2.5 & $0(0,2)$ & $1.5(0,4)$ & $0(0.2)$ & $0(0,2)$ \\
3 & $0(0,2)$ & $3(0.5,4.5)$ & $1(0,2)$ & $0(0,1)$ \\
4 & $0(0,1)$ & $3.5(0,7)^{*}$ & $2(0,5.5)^{*}$ & $1.5(0,4)$ \\
6 & $0(0,0.5)$ & $6(3,6)^{*}$ & $0.5(0,5)^{*}$ & $5(2.9)$ \\
8 & $0(0,0)$ & $0(0,3)^{\dagger}$ & $5(0,10)^{*}$ & $3.5(1.7 .5) \dagger$ \\
12 & $0(0,1)$ & $\ddagger$ & $\ddagger$ & $5.5(1,10)^{\dagger}$ \\
16 & $0(0,0)$ & $\ddagger$ & $\ddagger$ & $5.5\left(1,10 \dagger^{\dagger}\right.$ \\
24 & $0(0,1)$ & $\ddagger$ & $\ddagger$ & $10(10,10)^{\dagger}$ \\
\hline
\end{tabular}

*Between five and ten subjects.

†Less than five subjects.

$\ddagger$ No subjects.

As shown in Table III, the median baseline pain score differences among patients who received morphine and those who received each dose of butorphanol were not statistically significantly different. The median pain scores were statistically different in the four treatment groups at $15,30,45$ and $60 \min (P<0.05)$. Although the scores were similar for the three butorphanol dosages these were consistently lower than those for morphine. At 90 min and two hours, the pain scores for butorphanol and morphine were almost equal. As shown in the Figure, the number of patients requesting supplemental medication, and dropping out of the study, increased progressively beyond $45 \mathrm{~min}$ in both the butorphanol- and morphine-

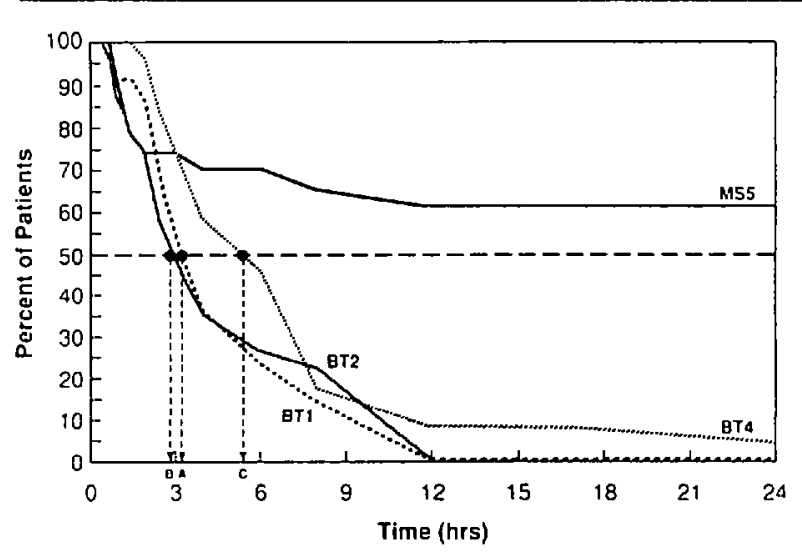

FIGURE Attrition profiles for the subjects. Median time (50 per cent of patients) in the study was $>24 \mathrm{hr}$ for morphine, and $3(\mathrm{~A}), 2.5$ (B) and $4(\mathrm{C}) \mathrm{hr}$, respectively for butorphanol, 1.2 or $4 \mathrm{mg}$. MS5 $=$ morphine, $5 \mathrm{mg}$; BTI = butorphanol, $1 \mathrm{mg}$; BT2 = butorphanol. $2 \mathrm{mg}$; BT4 = butorphanol, $4 \mathrm{mg}$.

treated patients. The attrition profiles for butorphanol were different from morphine $(P<0.01$, KruskalWallis). Further, the Figure illustrates that the median time in the study was: $>24(1.5,>24) \mathrm{hr}$ for morphine; and $3(2.0,4.5), 2.5(1.5,6.0)$ and $4.0(2.6,6.0) \mathrm{hr}$, respectively for butorphanol, 1,2 or $4 \mathrm{mg}$. Comparison of the pain score profiles over time (multivariate analysis of variance with repeated measures), suggested that the treatments were statistically nonparallel, i.e., that there was a significant treatment-time interaction $(P=0.001)$. Because of the potential bias introduced by the drop-out rate, statistical comparisons of the differences in pain scores beyond two hours were not performed.

The calculated median percentage pain relief values by treatment and time are shown in Table IV. Each dose of butorphanol produced greater pain relief than morphine at $15,30,45$ and $60 \mathrm{~min}(P<0.05)$. At $90 \mathrm{~min}$ and two

TABLE IV Calculated percent pain relief, ([baseline - treatment]/[baseline]), median (Ist, 3rd quartiles)

\begin{tabular}{|c|c|c|c|c|c|}
\hline \multirow[b]{3}{*}{$\begin{array}{l}\text { Time, } \\
\min \end{array}$} & \multicolumn{4}{|l|}{ Subject group } & \multirow[b]{3}{*}{ P-value* } \\
\hline & \multirow[b]{2}{*}{$\begin{array}{l}\text { Morphine } \\
5 \mathrm{mg}\end{array}$} & \multicolumn{3}{|l|}{ Busorphanol } & \\
\hline & & $/ \mathrm{mg}$ & $I m g$ & $4 m g$ & \\
\hline 15 & $25.0(-14.3 .75 .0)$ & $60.7(21.5,100.0)$ & $80.0(40.0 .100 .0)$ & $88.9(64.4,100.0)$ & $<0.001$ \\
\hline 30 & $58.3(11.1 .83 .3)$ & $100.0(68.6,100.0)$ & $100.0(80.0,100.0)$ & $100.0(80.8,100.0)$ & $<0.01$ \\
\hline 45 & $71.4(11.1,100.0)$ & $100.0(74.1,100.0)$ & $100.0(61.9,100.0)$ & $100.0(87.8,100.0)$ & $<0.05$ \\
\hline 60 & $66.7(29.2,100.0)$ & $100.0(90.6,100.0)$ & $100.0(76.2,100.0)$ & $100.0(84.4,100.0)$ & $<0.05$ \\
\hline 90 & $100.0(75.0,100.0)$ & $100.0(55.0,100.0)$ & $100.0(76.7,100.0)$ & $100.0(78.3,100.0)$ & NS \\
\hline 120 & $100.0(70.7,100.0)$ & $75.0(11.1,100.0)$ & $100.0(8.3,100.0)$ & $88.9(50.0,100.0)$ & NS \\
\hline
\end{tabular}

*Kruskal-Wallis 
TABLE V Heart rate (HR) and calculated mean blood pressure (BP) values, median (Ist, 3rd quartiles), HR, $\left(\mathrm{bpm}^{-1}\right)$ is the upper number, and $\mathrm{BP}(\mathrm{mmHg})$ the lower number in each pair at each time

\begin{tabular}{|c|c|c|c|c|c|}
\hline \multirow{3}{*}{$\begin{array}{l}\text { Time, } \\
\min \cdot h r^{-1}\end{array}$} & \multicolumn{4}{|l|}{ Subject group } & \multirow[b]{3}{*}{$P$-valuef } \\
\hline & \multirow{2}{*}{$\begin{array}{l}\text { Morphine } \\
5 \mathrm{mg}\end{array}$} & \multicolumn{3}{|l|}{ Butorphanol } & \\
\hline & & $l \mathrm{mg}$ & $2 m g$ & $4 \mathrm{mg}$ & \\
\hline Baseline & $\begin{array}{l}94.0(82.0,101.0) \\
93.3(87.3,101.7)\end{array}$ & $\begin{array}{l}82.0(73.5,94.0) \\
92.3(82.9,101.4)\end{array}$ & $\begin{array}{l}84.0(78.0,100.0) \\
86.7(76.7,94.7)\end{array}$ & $\begin{array}{l}79.5(70.5,96.0) \\
85.5(80.0,93.5)\end{array}$ & $\begin{array}{l}0.1 \\
0.0223\end{array}$ \\
\hline 30 & $\begin{array}{l}94.0(81.0,105.0) \\
95.0(83.3,103.3)\end{array}$ & $\begin{array}{l}87.0(71.8,101.2) \\
89.7(80.6,98.4)\end{array}$ & $\begin{array}{l}82.0(77.0 .90 .0) \\
84.0(79.3,89.3)\end{array}$ & $\begin{array}{l}88.0(78.0,102.0) \\
84.7(76.0 .88 .7)\end{array}$ & $\begin{array}{l}0.2 \\
0.0033\end{array}$ \\
\hline 60 & $\begin{array}{l}94.0(87.5,101.5) \\
92.7(86.7,100.3)\end{array}$ & $\begin{array}{l}83.0(74.0 .103 .0) \\
89.7(78.0,95.7)\end{array}$ & $\begin{array}{l}84.0(75.0,95.0) \\
81.7(77.4 .85 .8)\end{array}$ & $\begin{array}{l}85.0(73.5,96.8) \\
83.3(78.5,89.6)\end{array}$ & $\begin{array}{l}0.3 \\
0.0014\end{array}$ \\
\hline 90 & $\begin{array}{l}93.0(87.0,107.0) \\
95.2(87.6,97.4)\end{array}$ & $\begin{array}{l}82.5(69.0 .104 .0) \\
86.7(79.5,95.8)\end{array}$ & $\begin{array}{l}81.0(76.8,94.5) \\
82.2(78.4 .88 .0)\end{array}$ & $\begin{array}{l}91.0(75.2,98.0) \\
83.2(76.8,89.3)\end{array}$ & $\begin{array}{l}0.2 \\
0.0148\end{array}$ \\
\hline 2 & $\begin{array}{l}93.0(81.5,105.0) \\
90.7(87.8,95.7)\end{array}$ & $\begin{array}{l}80.5(71.0 .100 .5) \\
84.3(77.8,94.5)\end{array}$ & $\begin{array}{l}80.0(78.0,91.2) \\
84.8(80.9,88.8)\end{array}$ & $\begin{array}{l}84.0(74.0,96.0) \\
84.3(77.3,89.7)\end{array}$ & $\begin{array}{l}0.2 \\
0.07\end{array}$ \\
\hline 2.5 & $\begin{array}{l}90.0(83.5 .102 .5) \\
92.3(82.7 .95 .3)\end{array}$ & $\begin{array}{l}72.0(67.0,102.0) \\
85.7(77.3,93.3)\end{array}$ & $\begin{array}{l}80.0(70.0,89.5) \\
85.3(79.8,88.0)\end{array}$ & $\begin{array}{l}85.0(75.2,100.2) \\
85.3(79.5 .92 .5)\end{array}$ & $\begin{array}{l}0.1 \\
0.4\end{array}$ \\
\hline 3 & $\begin{array}{l}94.0(84.0,106.5) \\
86.3(78.8,96.5)\end{array}$ & $\begin{array}{l}75.0(67.0,100.5) \\
88.7(78.7,94.3)\end{array}$ & $\begin{array}{l}75.5(68.8,80.5) \\
82.5(80.8,89.5)\end{array}$ & $\begin{array}{l}83.0(71.8,93.2) \\
89.0(83.3,92.0)\end{array}$ & $\|$ \\
\hline 4 & $\begin{array}{l}88.5(81.2,115.2) \\
87.7(78.7,96.8)\end{array}$ & $\begin{array}{l}64.5(61.2 .96 .5)^{*} \\
85.2(77.8,97.5)^{*}\end{array}$ & $\begin{array}{l}73.0(63.8,82.0)^{*} \\
84.2(79.2,85.8)^{*}\end{array}$ & $\begin{array}{l}83.0(73 \cdot 2,89.0) \\
86.2(84.2,91.1)\end{array}$ & $\begin{array}{l}\| \\
\|\end{array}$ \\
\hline 6 & $\begin{array}{l}91.0(85.5 .104 .2) \\
89.2(83.7 .95 .3)\end{array}$ & $\begin{array}{l}68.0(61.5,102.0)^{*} \\
87.3(81.3,103.8)^{*}\end{array}$ & $\begin{array}{l}72.0(65.5,86.0)^{*} \\
82.0(79.8,93.3)^{*}\end{array}$ & $\begin{array}{l}83.5(77.2,91.8) \\
90.3(87.6,92,8)\end{array}$ & $\|$ \\
\hline 8 & $\begin{array}{l}91.0(84.0,110.0) \\
88.7(82.3,94.0)\end{array}$ & $\begin{array}{l}73.0(68.0,100.0) \dagger \\
95.7(90.7,100.0) \dagger\end{array}$ & $\begin{array}{l}74.0(68.0 .87 .5)^{\dagger} \\
91.3(78.7,98.0)^{\dagger}\end{array}$ & $\begin{array}{l}91.0(85.5,95.0)^{\dagger} \\
88.3(84.7,100.5)^{\dagger}\end{array}$ & $\|$ \\
\hline 12 & $\begin{array}{l}95.0(77.5,104.2) \\
90.5(81.6,92.9)\end{array}$ & $\begin{array}{l}\ddagger \\
\ddagger\end{array}$ & $\begin{array}{l}\ddagger \\
\ddagger\end{array}$ & $\begin{array}{l}98.0(98.0,98.0) \S \\
96.7(96.7,96.7) \S\end{array}$ & $\|$ \\
\hline 16 & $\begin{array}{l}86.0(79.5,101.0) \\
93.3(88.7,97.3)\end{array}$ & $\begin{array}{l}\ddagger \\
\ddagger\end{array}$ & $\begin{array}{l}\ddagger \\
\ddagger\end{array}$ & $\begin{array}{l}88.0(88.0,88.0) \$ \\
97.3(97.3,97.3) \S\end{array}$ & $\|$ \\
\hline 24 & $\begin{array}{l}88.0(86.0 .96 .0) \\
90.0(85.8 .97 .5)\end{array}$ & $\begin{array}{l}\ddagger \\
\ddagger\end{array}$ & $\begin{array}{l}\ddagger \\
\ddagger\end{array}$ & $\begin{array}{l}90.0(90.0,90.0) \\
94.0(94.0 .94 .0) \$\end{array}$ & $\|$ \\
\hline
\end{tabular}

*Between five and ten subjects.

†Less than five subjects.

$\ddagger$ No subjects.

\$One subject.

"Analysis not performed duc to possible bias from attrition.

hours each dose of butorphanol and morphine produced similar pain relief. To test whether the pain relief profiles over time were similar, a multivariate analysis of variance with repeated measures (BMDP5V) was performed. This analysis suggested that the profiles were statistically nonparallel (i.e., there was a treatment-time interaction; $P<0.05$ ). Unfortunately, because of the very heavy negative skew in the data, none of the simple transformations (log, antilog, square root, inverse) yield anything close to approximately normal distributions. Thus, the results of this analysis which assumes normally distributed data are suspect. The authors are unaware of a satisfactory solution to this dilemma. The results of the analysis agree with visual inspection of the data, i.e., the morphine profile is clearly different from the butorphanol profiles. The comparisons at each time point were carried out using the rank-based, non-parametric Kruskal-Wallis test which is not affected by the heavy skew.

The heart rate and blood pressure changes by treatment and time are shown in Table $V$. These profiles were compared over time using a multivariate analysis of variance with repeated measures (BMDP5V). The heart rate analysis indicated that the profiles were not significantly different (i.e., the treatment-time interaction was not significant, treatment-effect was not significant, and the time-effect was not significant). The blood pressure analysis indicates that the mean blood pressure trends were parallel (i.e., the treatment-time interaction was not significant, that there was a time-effect, $P<0.001$, and a treatment-effect, $P<0.001$ ). However, in each instance 
the profiles may have been biased by attrition of patients from the study beyond $2.5 \mathrm{hr}$.

None of the patients experienced a decrease in respiratory rate below 12 breaths $\cdot \mathrm{min}^{-1}$, nausea, or vomiting. Although most patients readily drifted off to sleep at some time during the study, they were easily arousable. One patient ( 1.4 per cent) who received butorphanol developed pruritus compared with ten patients ( 43 per cent) who had received morphine $(P<0.0001)$. The presence of urinary retention was not evaluated since indwelling urinary catheters were used routinely for $24 \mathrm{hr}$ postoperatively.

The median global pain assessment of the epidural analgesia following morphine was $4(2,5)$, compared with $3(2,4), 3(2,4)$ and $4(3,5)$, respectively following butorphanol 1,2 or $4 \mathrm{mg}$. These differences were not statistically significant.

\section{Discussion}

The results of the present study demonstrate that epidural butorphanol or morphine provide effective postoperative analgesia following Caesarean section. The mean median pain scores $15,30,45$ and $60 \mathrm{~min}$ following each dose of butorphanol were significantly lower than the corresponding values in the patients who received morphine. Thus the time to onset of epidural analgesia following butorphanol was more rapid than following morphine. Beyond $45 \mathrm{~min}$ after epidural administration of either drug, there was a progressive increase in the number of patients who requested supplemental medication. However, it may be of practical clinical interest that 14,22 and 17 per cent of patients treated with butorphanol 1, 2 or $4 \mathrm{mg}$ respectively, had not requested supplemental medication at eight hours, and that one in the latter group had adequate analgesia for $24 \mathrm{hr}$. In contrast, 65 per cent of the morphine patients had not been remedicated at eight hours and 61 per cent had adequate analgesia for $24 \mathrm{hr}$.

Pruritus occurred in only 1.4 per cent of the butorphanol patients compared with 43 per cent of the morphine patients. Importantly, pruritus following either drug responded promptly to either intravenous diphenhydramine or naloxone. The global assessments of the adequacy of epidural analgesia following butorphanol were essentially indistinguishable from those following morphine.

Abboud et al. ${ }^{15}$ evaluated the respiratory effects of butorphanol using the ventilatory responses to progressive hypercapni. A decrease in the central sensitivity to $\mathrm{CO}_{2}$ was observed as early as $1.5 \mathrm{hr}$ after administration and lasted between 6-12 hr. Morphine produced persistent respiratory depression of $24 \mathrm{hr}$ duration. In a recent letter, Lippman and Mok quoted unpublished data that 4 mg of epidural butorphanol produced elevations in $\mathrm{PaCO}_{2}$ although clinically significant respiratory depression, i.e., a respiratory rate less than 10 breaths $\cdot \min ^{-1}$, was not observed. ${ }^{20}$ Since neither $\mathrm{CO}_{2}$ responses nor $\mathrm{PaCO}_{2}$ was measured in our patients, we can neither support nor refute these observations.

An acute abstinence syndrome has been reported following the epidural injection of butorphanol after Caesarean delivery. ${ }^{21}$ This case report suggests that it is advisable to avoid the use of butorphanol in patients with a history of substance abuse.

The present data support the conclusion that epidural butorphanol is safe and effective in providing postoperative analgesia. Importantly, the calculated pain relief scores following each dose of butorphanol were significantly lower than morphine 15,30 and 45 min following administration. The more rapid onset of analgesia following epidural butorphanol suggests that the drug may be particularly useful in clinical situations where: (1) a prompt onset and/or limited duration of analgesic action may be indicated, and (2) with epidural patient-controlled analgesia (PCA). Further, the present results suggest that a combination of epidural butorphanol and morphine might provide a more prompt onset and more stable level of analgesia for $24 \mathrm{hr}$ or longer. However, to our knowledge, the use of such a combination has not been reported. Although none of the patients in the present study developed a respiratory rate below 12 breaths $\cdot \min ^{-1}$, we concur with others ${ }^{16}$ that observation for clinical respiratory depression is indicated during the period of analgesia following butorphanol as it is with other epidural opioids.

\section{References}

I Behar M, Magora F, Olshwang D, Davidson JT. Epidural morphine in treatment of pain. Lancet 1979; 1: 527-8.

2 Bromage PR, Camporesi E, Chestnut D. Epidural narcotics for postoperative analgesia. Anesth Analg 1980; 59: 473-80.

3 Rawal N, Sjostrand U, Dahlstrom B. Postoperative pain relicf by epidural morphine. Anesth Analg 1981;60: 726-31

4 Coombs DW, Danielson DR, Pageau MG, Rippe E. Epidurally administered morphine for post-cesarean analgesia. Surg Gynecol Obstet 1982; 154: 385-8.

5 Cohen SE, Woods WA. The role of epidural morphine in the postcesarean patient: efficacy and effects on bonding. Anesthesiology 1983; 58: 500-4.

6 Rosen MA, Hughes SC, Shnider SM et al. Epidural morphine for the rclief of postoperative pain after cesarean section. Anesth Analg 1983; 62: 666-72.

7 Kotelko DM, Dailey PA, Shnider SM et al. Epidural morphine analgesia after cesarean section. Obstet Gynecol 1984; 63: 409-12. 
8 Binsted RJ. Epidural morphine after caesarean section. Anaesth Intensive Care 1983; 11: 130-4.

9 Reiz $S$, Westberg $M$. Side-cffects of epidural morphinc. Lancet 1980; 2: 203-4.

10 Bromage PR, Camporesi EM. Durant PAC. Nonrespiratory side effects of epidural morphine. Anesth Analg 1982; 61: 490-5.

11 Gustafsson LL, Schildt B, Jacobsen K. Adverse effects of extradural and intrathecal opiates: report of a nationwide survey in Sweden. Br J Anaesth 1982; 1: 479-85.

12 Findlay JWA, Butz RF. Teeple E, Ghia JN. Biphasic depression of ventilatory responses to $\mathrm{CO}_{2}$ following epidural morphine. Anesthesiology 1983; 58: 418-27.

13 Bromage PR, Camporesi EM, Durant PAC, Nielson $\mathrm{CH}$. Rostral spread of epidural morphine. Anesthesiology 1982; 56: 431-6.

14 Mok MS, Tsai YJ, Ho WM et al. Efficacy of epidural butorphanol compared to morphine for the relief of postoperative pain. Anesthesiology 1986; 65: A175.

15 Abboud TK, Moore M. Zhu J et al. Epidural butorphanol or morphine for the relief of post-cesarean section pain: ventilatory responses to carbon dioxide. Anesth Analg 1987; 66: 887-93.

16 Ackerman WE, Juneja MM, Colclough GW. A comparison of epidural fentanyl, buprenorphine and butorphanol for the management of post cesarean section pain. Anesthesiology 1988; 69: A401.

17 McCormack HM, Horne DJL, Sheather S. Clinical application of visual analogue scales: a critical review. Physch Med 1988; 18: 1007-19.

18 Rosen MA, Hughes SC, Shnider SM et al. Epidural morphine for the relief of postoperative pain after cesarean delivery. Anesth Analg 1983; 62: 666-72.

19 Riegelman RK, Hirsch RP. Studying a study and testing a test. In: How to Read the Medical Literature. Boston: Little Brown, 1989; 256.

20 Lippman M, Mok MS. Epidural butorphanol for the relief of postoperative pain. Ancsth Analg 1988; 67: 418.

21 Weintraub SJ, Naulty JS. Acutc abstinence syndrome after epidural injection of butorphanol. Ancsth Analg 1985; 64: 452-3. 